\title{
MARKOS-KUJBUS Éva \\ AZ ON-LINE SZÁJREKLÁM \\ (ELECTRONIC WORD-OF-MOUTH) \\ JELLEMZŐI A MARKETINGKOMMUNIKÁCIÓ SZEMPONTJÁBÓL
}

\begin{abstract}
Az on-line térben a vállalatok elveszítik a hagyományos tömegkommunikációban gyakorolt kontrollt, ugyanakkor kommunikációs szerepükből fakadóan megmarad egy ráhatási képességük. Ahhoz azonban, hogy e ráhatási képességet ki tudják használni, megfeleló eszközöket kell alkalmazniuk, amelyek közül az egyik lehetőség az on-line szájreklám (electronic word-of-mouth, e-WOM). A cikk egy szakirodalmi összefoglalót nyújt az e-WOM-ról, kitérve arra, hogy milyen új kommunikációs kihívásokkal és lehetőségekkel néznek szembe a fogyasztók és a vállalatok az on-line térben. Továbbá hogyan értelmezhetó az e-WOM, milyen alapvető tulajdonságokkal és a fogyasztókra, valamint a vállalatokra gyakorolt hatásokkal rendelkezik. Ezen ismeretekre építve pedig a szerzó bemutatja azt is, hogy a fogyasztók között zajló on-line kommunikáció (vagyis az e-WOM) hogyan integrálható a marketingkommunikációs tevékenységbe.
\end{abstract}

Kulcsszavak: marketingkommunikáció, on-line szájreklám (e-WOM), on-line kommunikáció, szájreklám marketing (word-of-mouth marketing)

Az elmúlt években és még napjainkban is egy kommunikációs paradigmaváltás zajlik, amely során egy strukturális jellegú forradalom ment (megy) végbe az emberi kommunikációban, elsősorban a technológiai fejlődés hatására. A strukturális változás a kommunikációban azt jelenti, hogy megváltozik az emberek térrel és idővel kapcsolatos érzékelése. $E$ változások több formában jelennek meg: az egyre inkább interaktív kommunikációban a vállalatok és a fogyasztók között, valamint a felhasználók között is intenzíven áramlik az információ, mely akár egy idóben, akár aszinkron módon, illetve egy irányban, vagy több irányban is történhet. Ellentétben a fizetett (paid) médiára épülő, hagyományosnak nevezhető marketingkommunikációval, a vállalatok a digitális térben a fogyasztókat és az információt kevésbé képesek irányítani (szerzett (earned) média táguló környezete). Kommunikációs súlyukból fakadóan megmarad egy ráhatási képességük, a velük szemben kialakult kommunikáció irányítása pedig továbbra is a marketingkommunikációs tevékenység inherens tulajdonsága marad. Ahhoz azonban, hogy e ráhatási képességet ki tudják használni, megfelelő eszközöket kell alkalmazniuk. Ehhez nyújthat segítséget az on-line szájreklám (electronic word-of-mouth, e-WOM) fogalomköre. (Az on-line szájreklám rövidítéseként a továbbiakban az e-WOM rövidítést használom az egyszerú- ség kedvéért, azonban a szakirodalmakban elterjedt még az eWOM írásmódja (pl. Hennig-Thurau et al., 2004) is.)

Az e-WOM egyszerre kommunikációs csatorna és eszköz. Kommunikációs jelenségként és csatornaként alapvetően a fogyasztók közötti kommunikáció áramlását támogatja, ahol a fogyasztók adott termékkel/szolgáltatással kapcsolatos tapasztalataikat, élményeiket, gondolataikat osztják meg egymással. Habár ezek alapján ez alapvetően egy fogyasztók között zajló kommunikációs jelenség, a vállalat megpróbálhat részt venni ebben a folyamatban az ôt érintő információk áramlásának befolyásolásával, így számára az e-WOM eszközzé lép elő. Az e-WOM marketing alkalmazásához azonban szükséges mélyebben megismerni az e-WOM-ot mint jelenséget. Ugyanakkor itt fontos megjegyeznünk, hogy nem egy új jelenségről beszélünk, hiszen az alapvető mechanizmusok az off-line és az on-line térben ugyanazok.

Az e-WOM aktualitását és jelentőségét támasztja alá többek között, hogy a felnőtt internethasználók 79 százaléka nézi meg az on-line véleményeket vásárlás előtt (eMarketer, 2014), továbbá a felhasználók közel 80 százaléka bízik valamilyen szinten az on-line véleményekben (Statista, 2015). Az e-WOM jelenségének egyre nagyobb mértékú elterjedését mutatja, hogy a fogyasztók nemcsak olvassák, hanem létre is hozzák ezeket a tartalmakat, hi- 
szen 54 százalékuk hagy pozitív, 57 százalékuk vegyes és 21 százalékuk rossz értékelést egy adott termékról vagy szolgáltatásról (eMarketer, 2015).

\section{A megváltozott környezet és a szereplók}

A technológiai változás számos ponton befolyásolja a marketingkommunikáció gyakorlatát. A kommunikációs tér átalakulása egy meglehetősen komplex környezetet teremt a vállalatok számára, alapvetően megváltoztatva a kommunikáció jellemzőit, amely folyamatban egyre több résztvevő jelenik meg. E folyamat mentén a fogyasztók kommunikációs szokásai és elvárásai is átalakulóban vannak, amivel párhuzamosan a vállalatok fokozatosan veszítik el a domináns kommunikáló szerepét. E folyamatok eredményeként a vállalatok befolyásolási lehetősége beszúküil, az új felületek mentén a fogyasztók célzott elérésének lehetősége egyszersmind tágul is.

$\mathrm{Az}$ on-line felületek sajátosságai lehetôvé teszik az azonnali és tömeges információáramlást és továbbítást, valamint az alulról történő építkezést (pl. fogyasztók által történő kezdeményezést), az információ személyre szabhatóságát és az elméletileg végtelen célcsoport-elérést (Fehér, 2011; Vilpponen - Sundqvist, 2006). A megváltozott körülmények miatt az on-line tér merőben újfajta szemléletmódot igényel: a technológia szerepe immár nem a kommunikáció (eló)segítésére korlátozódik, hanem maga válik a kommunikációs tevékenység alapjává (Lievrouw, 2009).

A digitális környezet elterjedése több problémát is eredményez, amely egyrészt a megnövekedett információmennyiségnek, másrészt pedig a kommunikációs lehetôségek kibővülésének tudható be: ilyen probléma lehet a hitelesség, a megbízhatóság és az ellenőrizhetőség kérdése. Az on-line felületek egyik legnagyobb hátrányának tekinthető, hogy a fogyasztónak anonim módon vagy álnév alatt lehetósége van véleményt írni akár olyan tapasztalatáról is, amely meg sem történt (Rab, 2011), ezáltal olyan információk is kerülnek az információs körforgásba, amelyet a fogyasztó semmilyen módon sem tud ellenőrizni. Éppen ezért kiemelten fontos témakör az on-line információkkal szembeni bizalom vizsgálata (Archer-Brown et al., 2013), és annak erósítése a szolgáltatók által, különböző módszerekkel (pl. véleményt csak teljes névvel írhat a fogyasztó, több adatot meg kell adnia a véleményezőnek önmagáról stb.). Egy másik problémának a könnyen másolható és módosítható információk kérdésköre tekinthetô, amely akár az eredeti üzenet eltérítését is eredményezheti (Park - Lee, 2009).

A világhálón létrejövő kommunikáció olyan sajátos jellemzőkkel bír, mint a végtelen elérés, a szinkron és aszinkron kommunikáció egyidejú lehetősége, valamint a fokozott interaktivitás (Vilpponen - Sunqvist, 2006). Ugyanakkor értelmezésünkben az on-line fe- lületek gazdasági kommunikációra gyakorolt legjelentősebb hatása, hogy az információ létrehozásában már a fogyasztók is tömegesen részt vehetnek. Az új környezetben a fogyasztó is jelentős szerephez jut, passzív megfigyelőből aktív résztvevővé válik (Napoli, 2008). A fogyasztók kommunikációs lehetőségeinek köre kibővül, ezáltal szerepük is változik, a résztvevők tartalomfogyasztókból maguk is tartalom-elóállítókká is válhatnak (Botha et al., 2011).

A fogyasztók reakciója a vállalatokkal szembeni elégedetlenségük esetén a kivonulás (exit) vagy véleménynyilvánítás (voice) formáiban (Hirschman, 1970) nyilvánulhat meg. Amíg kivonulás esetén nem vásárolja tovább az adott vállalat termékeit vagy veszi igénybe szolgáltatásait, addig a véleménynyilvánítás esetében negatív - de akár pozitív - élményét és véleményét kinyilváníthatja a vállalatnak, vagy ismerőseinek és a többi fogyasztónak is. Az on-line térben ezek a reakciók látványosabban jelennek meg, mint korábban az off-line térben, hatásuk és elterjedésük is nagyobb lehet az általános elérhetőség és visszakereshetóség hatására. A vélemények kifejezésének lehetőségei is bővülttek, hiszen a fogyasztóra számos lehetősége van a különböző közösségimédia-felületektől kezdve, az értékelő rendszereken át (pl. webshopban), a kizárólag a fogyasztók véleményezését tartalmazó oldalakig (pl. TripAdvisor) bezárólag (Napoli, 2008).

A fenti tényezők vezetnek a digitális térben a fogyasztók on-line felhatalmazódásának jelenségéhez (consumer empowerment), amely során „a felhasználók szerepet kapnak nézeteik kifejezéséhez, s ezen keresztül saját fogyasztásuk befolyásolásához" (Csordás, 2016, p. 21.). Ez azt is jelenti, hogy a vállalatoknak a fogyasztókra már nem passzív befogadóként kell tekintenie, hanem mint aktív és ellenőrzést igénylő szereplőre, aki tudatosan fel is használja az irányítás és hatalom azon eszközeit, amiket a fogyasztási folyamat során szerzett, ezzel saját élményeket és jelentéseket konstruálva fogyasztása köré (Markos-Kujbus - Csordás, 2015).

A fogyasztók szerepkörével párhuzamosan átalakultak kommunikációs szokásaik is (Archer-Brown et al. 2013; Kozinets, 1999; Fehér, 2011): az információszerzési folyamat felgyorsult, ső́t elvárássá vált az információhoz való azonnali hozzáférhetőség. Kibővültek továbbá az információfogyasztás lehetôségei is, hiszen a fogyasztónak az on-line térben nagyobb választási és ellenőrzési lehetősége van arra vonatkozóan, hogy mit, mikor, hol és hogyan fogyaszt (Napoli, 2008) (1. ábra). A korábbiakban írtak miatt pedig az információ immár nemcsak statikus „termék”, amelyet fogyasztanak vagy továbbítanak, hanem dinamikus „erőforrás” is, amelyet a fogyasztók felhasználhatnak és módosíthatnak saját üzenetük átadásához. Ezáltal pedig az információ útját is képesek befolyásolni (Green - Jenkins, 2011). 


\section{A fogyasztók megváltozott információfogyasztási lehetôségei az on-line térben}

\begin{tabular}{|c|}
\hline \multicolumn{1}{|c|}{ MIT? } \\
\hline • vállalattól kapott \\
információ \\
ÉS \\
• felhasználóktól (pl. \\
fogyasztótól és 3. \\
független vállalattól) \\
kapott információ \\
ÉS \\
• önmaga által (át)alakított \\
tartalom \\
ÉS \\
•önmaga által létrehozott \\
tartalom \\
\end{tabular}

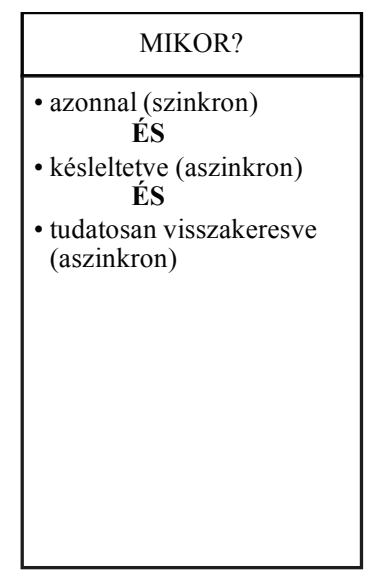

A digitális térben emellett megfigyelhető a közösségek felértékelődése az információáramlás és a kommunikáció folyamatában. A virtuális közösségek fontosságát jelöli a törzsi marketing is (Cova - Cova, 2002): amely elsősorban a fogyasztó-fogyasztó kapcsolatra fókuszál, vagyis az interaktív kommunikációra épít. Továbbá a vállalat a kapcsolat támogatójaként jelenik meg ebben a felfogásban, amely szerint a vállalat feladata nemcsak a vállalat és fogyasztó, de a fogyasztók közötti kommunikáció elősegítése is. A kapcsolat során cél a törzs (közösség) létrehozása, amelyhez különböző rítusokat használ fel a vállalat az off-line közösségekhez hasonló múködési felfogásban. Továbbá elsődleges cél az érzelmi lojalitás kialakítása a törzs tagjaiban, amely által versenyelónyre tehet szert a vállalat. Azonban fontos megjegyezni, hogy a fogyasztók azon egyénekkel és márkákkal fognak kapcsolatban lépni ezekben a közösségekben, akiket autentikusnak gondolnak, éppen ezért a bizalom szintén kiemelt tényezó kell, hogy legyen ezekben a kapcsolatokban is (Archer-Brown et al., 2013). Ugyanakkor a fogyasztók a márkákkal való kapcsolatban elvárják, hogy ne csak meghallgassák őet, de válaszoljanak nekik és legyen elkötelezett a vállalat a fogyasztói felé (Bonchek, 2015).

$\mathrm{Az}$ on-line közösségekben a vállalatok közvetlen kapcsolatba kerülhetnek azon fogyasztóikkal, akikkel együtt hozhatnak létre tartalmakat, ezáltal erósítve a vállalat és a fogyasztó közötti kapcsolatot. Ezen együttmúködés eredménye, hogy az érintett fogyasztók nagyobb valószínúséggel lesznek húségesek a vállalathoz (Godes - Mayzlin, 2004).

$\mathrm{Az}$ e-WOM megismerésének szükségességét támasztja alá az, hogy a WOM-ban résztvevők összessége értelmezhető egyfajta közösségként (Scarpi, 2010).
Forrás: saját szerkesztés
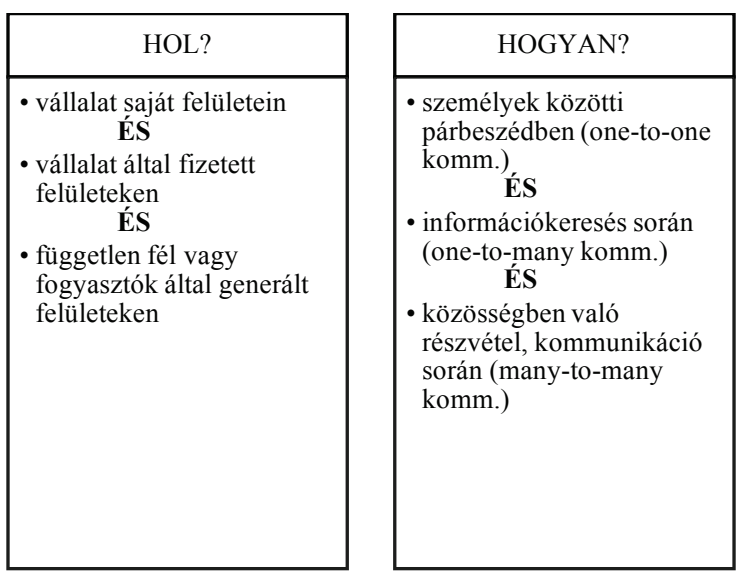

Egy közös érdeklődési pont összeköti a résztvevőket, valamint jellemzően csak on-line kommunikációs csatornák segítségével kerülnek egymással kapcsolatba, ahol elsődleges céljuk a tapasztalatok és információ megosztása és cseréje. Azonban közösségként gyenge és erős kapcsolat felváltva jelenhet meg a résztvevők között, valamint a kooperáció mértéke is változó lehet. Továbbá egyfajta társas egyezmény és a tagság érzése is létezhet az e-WOM során, hiszen összeköti őket az adott termék vagy szolgáltatás.

\section{Az e-WOM fogalmának alakulása}

Amint láthatóvá vált, megváltoztak a kommunikációs szokások és eszközök a technológia fejlődésével. Ebben a megváltozott térben egyre nagyobb hangsúlyt kap az e-WOM, hiszen Eszes (2010) szerint a fogyasztók hozzáállása egyre szkeptikusabb a vállalati marketingüzenetekkel szemben, a megnövekedett reklámzaj miatt, aminek a hatására egyre inkább a független információforrások felé fordulnak.

A WOM hagyományosan elfogadott tulajdonsága, hogy az egyik legbefolyásosabb erőforrás az információátvitelben, és a fogyasztók egymás közötti termékinformáció-átadása sokkal hatékonyabb, mint a személyes eladás (Katz - Lazarsfeld, 1955). Ennek magyarázata, hogy a fogyasztók megbízhatónak és hitelesnek (valamint általában vállalattól függetlennek (Okazaki, 2009)) vélik ezt a kommunikációs formát.

A technológiai fejlődés különösen nagy hatással volt a WOM fogalmára is, hiszen az új, on-line felületeken is megtalálható a WOM-kommunikáció. A legfontosabb definíciós elemek között jelent meg, hogy a kommuni- 
káció tárgya lehet a termék, a márka, egy szolgáltatás vagy akár egy szervezet is, de továbbra is feltétel, hogy magát a kommunikációt nem befolyásolja a vállalat (Litvin et al., 2008). Ezt a megközelítést kibővítve alkották meg Hennig-Thurau és munkatársai (2004, p. 39.) a szakirodalom által leggyakrabban hivatkozott e-WOM definíciót. E szerint e-WOM alatt értünk ,,minden olyan pozitív vagy negatív hozzászólást, amelyet jelenlegi, potenciális vagy korábbi fogyasztók tesznek közzé egy termékroól/szolgáltatásról vagy vállalatról, és amely hozzászólások több fogyasztó számára elérhetôk az internet felületén keresztül." Cheung és Thadani (2012) szerint e hozzászólások többnyire verbális ingereket közvetítenek és céljuk, hogy a többi fogyasztó magatartását módosítsák.

Az e-WOM továbbá értelmezhetô a személyközi interperszonális kommunikációnak a virtuális térre való kiterjesztéseként, amelyben pozitív és negatív információk egyaránt megjelenhetnek (Csordás et al., 2012), il- letve egyszerre jelennek meg az információkeresó és az információmegosztó szerepkörök.

Az e-WOM definíciójának alakulását mutatja be az 1. táblázat.

A táblázat alapján a továbbiakban az alábbi definíciót fogadjuk el: az e-WOM a társas befolyásolás és a kommunikáció egy formájának tekinthető, amely alapvetően fogyasztók között zajlik. Folyamatában az e-WOM küldôje (forrása) - aki múltbeli, aktuális vagy potenciális érintett (stakeholder) - többnyire verbális ingereket közvetít a közönség felé. Azonban képes ezt helyettesíteni vagy kiegészíteni teljes mértékben vizuális és/vagy audiovizuális ingerekkel. Az ingerek tartalma bármilyen pozitív, semleges vagy negatív információ lehet a termékről, szolgáltatásról, márkáról, vállalatról vagy személyről. Ezen ingerek egyaránt elérhetőek az on-line felületeken a fogyasztók és a szervezetek számára. A fogyasztók a folyamatban egyszerre jelennek meg az információkeresó és az információmegosztó szerepkörök.

\section{Az e-WOM definíciójának alakulása}

\begin{tabular}{|c|c|}
\hline SZERZÖ & AZ E-WOM FÖBB DEFINÍCIÓS ELEMEI \\
\hline Bergamo - Bagozzi, 2000 & $\begin{array}{l}\text { az e-WOM-ban résztvevő́k csoportja felfogható egy informális hálózatként, } \\
\text { információforrások és keresôk egy társas identitás érzésén keresztül kap- } \\
\text { csolódnak }\end{array}$ \\
\hline $\begin{array}{l}\text { Hennig-Thurau et al., 2004; Litvin } \\
\text { et al., } 2008\end{array}$ & $\begin{array}{l}\text { a kommunikáció tárgya lehet a termék, a márka, egy szolgáltatás vagy akár } \\
\text { egy szervezet is }\end{array}$ \\
\hline $\begin{array}{l}\text { Dellarocas, 2003; Sen - Lerman, } \\
2007\end{array}$ & $\begin{array}{l}\text { gyakran olyan egyének között lezajló folyamat, akik között minimális vagy } \\
\text { egyáltalán nincs is valódi kapcsolat }\end{array}$ \\
\hline De Bruyn - Lillian, 2004 & $\begin{array}{l}\text { C2C kommunikáció egy termékról vagy szolgáltatásról, amely segíti a ter- } \\
\text { mék vagy szolgáltatás adaptációját }\end{array}$ \\
\hline Hennig-Thurau et al., 2004 & $\begin{array}{l}\text { pozitív vagy negatív állítás, amelyet jelenlegi, potenciális vagy korábbi fo- } \\
\text { gyasztók tesznek közzé egy termékről/szolgáltatásról vagy vállalatról, és } \\
\text { amely hozzászólások több fogyasztó számára elérhetôek az internet felüle- } \\
\text { tén keresztül. }\end{array}$ \\
\hline al., 2008 & $\begin{array}{l}\text { minden internet-alapú technológián keresztül megvalósuló informális kom- } \\
\text { munikáció, ami a fogyasztók felé irányul, és jószágok, szolgáltatások vagy } \\
\text { eladóik jellemzőihez vagy használatához kötődik }\end{array}$ \\
\hline - Thadani, 2012 & $\begin{array}{l}\text { a társas kommunikáció egy új formájának tekinthetô, amely folyamatban } \\
\text { a kommunikátor stimulikat (többnyire verbális szimbólumokat) ad át azon } \\
\text { célból, hogy más egyének magatartását módosítsa }\end{array}$ \\
\hline Cheung - Thadani, 2012 & $\begin{array}{l}\text { a folyamatban egyszerre jelennek meg az információkeresók és a megosz- } \\
\text { tók (a fogadók és küldők, mint fogyasztók); az e-WOM kommunikáció a } \\
\text { személyes/társas befolyásolás egy típusának tekinthető (hasonlóan a hagyo- } \\
\text { mányos típushoz) }\end{array}$ \\
\hline Yap et al., 2013 & $\begin{array}{l}\text { az e-WOM több a szavaknál, a tényleges értelmét az adja meg, ahogyan } \\
\text { mondják }\end{array}$ \\
\hline Csordás et al., 2012 & gyományos \\
\hline
\end{tabular}




\section{A reklám és az e-WOM fogalmak megkülönböztetése}

A WOM definíciójának egyik eleme, hogy a szájreklám folyamatában résztvevók egyike sem lehet a vállalat képviselője (Bone, 1995). Emiatt a szájreklám nem tekinthetô a fizetett hirdetés egy típusának, mégis gyakori hibaként fordul elô a két fogalom keveredése (Armelini - Villanueva, 2010). Az e-WOM így számos tekintetben szembeállítható a reklám fogalomkörével (2. táblázat). Definíció szerint a hagyományos reklám egy azonosítható forrásból származó, harmadik fél (médium) által közvetített, fizetett hirdetési formátum (Kotler - Keller, 2006, p. 695.; Sándor - Horváth, 2008, p. 46.), addig az e-WOM - ahogy láthatóvá vált az összegző definí- cióban - alapvetốen vállalattól független, fogyasztótól származó információ és csatorna, az üzenet küldóje pedig sokszor ismeretlen.

A klasszikus reklám esetében hagyományos tömegkommunikációról beszélünk, amely során a vállalat teljes körú kontrollal rendelkezik a közvetítő médium kiválasztásában, a kibocsátott üzenetben és az üzenet sugárzásának gyakoriságának és dinamikájának kialakításában. Ezzel szemben az e-WOM esetében elenyésző a vállalat ráhatása az üzenetekre és azok dinamikájára, marketingkommunikációs szempontból szerzett médiáról (earned media) beszélhetünk (Corcoran, 2006).

A klasszikus reklám esetében a küldő és fogadó között hagyományos, a tömegkommunikációra jellem-

\section{Az e-WOM és a klasszikus reklám összehasonlítása}

\begin{tabular}{|c|c|c|}
\hline & REKLÁM & E-WOM \\
\hline $\begin{array}{l}\text { küldő-fogadó } \\
\text { kapcsolatának típusa }\end{array}$ & döntó részben one-to-many & $\begin{array}{l}\text { mind a három típus lehetséges } \\
\text { (one-to-many; one-to-one; many-to-many) }\end{array}$ \\
\hline $\begin{array}{l}\text { küldő-fogadó } \\
\text { kapcsolatának szorossága }\end{array}$ & jellemzően gyenge & változó \\
\hline $\begin{array}{l}\text { a forrás/küldő } \\
\text { azonosíthatósága }\end{array}$ & jól azonosítható & változó \\
\hline $\begin{array}{l}\text { kapott információ } \\
\text { megítélése }\end{array}$ & több tényező alapján is történhet & nehézkes \\
\hline hitelesség & $\begin{array}{l}\text { változó észlelt hitelesség, az e-WOM-nál } \\
\text { jellemzően alacsonyabb szint }\end{array}$ & magasabb észlelt hitelesség \\
\hline fogyasztói reakció & $\begin{array}{l}\text { gyakran tolakodónak és zavarónak tart- } \\
\text { ják, így elutasítják - hiszen tartalommeg- } \\
\text { szakító }\end{array}$ & $\begin{array}{l}\text { nem tolakodó, nem (vagy minimálisan) } \\
\text { zavaró - hiszen az e-WOM maga a tar- } \\
\text { talom }\end{array}$ \\
\hline fogyasztók elérhetősége & tervezhetőbb & kevésbé tervezhető \\
\hline $\begin{array}{l}\text { ismertségre gyakorolt } \\
\text { hatás }\end{array}$ & tervezhetőbb & kevésbé tervezhető \\
\hline $\begin{array}{l}\text { márkaértékre gyakorolt } \\
\text { hatás }\end{array}$ & $\begin{array}{l}\text { növeli a márkaértéket (növeli a márkais- } \\
\text { mertséget, formálja a márka iránti attitú- } \\
\text { döt, támogatja a kipróbálást) }\end{array}$ & $\begin{array}{l}\text { növelheti a márkaértéket } \\
\text { (pozitív e-WOM), } \\
\text { csökkentheti a márka hitelességét } \\
\text { (negatív e-WOM) }\end{array}$ \\
\hline $\begin{array}{l}\text { értékesítésre gyakorolt } \\
\text { hatása }\end{array}$ & rövid távon növelheti & $\begin{array}{l}\text { rövid és hosszú távon, növelheti vagy } \\
\text { csökkenheti }\end{array}$ \\
\hline hatásának időtávja & rövid és hosszú távú hatás egyaránt & elsősorban hosszú távú hatás \\
\hline mérhetőség & egyezményes mérési módszerek, mutatók & korlátozott \\
\hline kontroll & $\begin{array}{l}\text { (szinte) teljes körú kontroll az üzenet, a } \\
\text { médium és a gyakoriság felett (paid me- } \\
\text { dia) }\end{array}$ & $\begin{array}{l}\text { elenyésző, de! ráhatási lehetôség létezik } \\
\text { (earned media, kisebb arányban owned/ } \\
\text { paid media) }\end{array}$ \\
\hline költség & alacsony & változó \\
\hline
\end{tabular}


ző one-to-many (egyén a tömeghez) kommunikációs forma jellemzó, míg az e-WOM esetében mind a három elterjedt kommunikációs forma előfordulhat. Így a digitális térben is értelmezhető hagyományos tömegkommunikáció (one-to-many) mellett lehetőség nyílik a különbözó interaktív csatornákon a személyes kommunikációra (one-to-one (egyén az egyénhez)), valamint a közösségi média segítségével a „tömeg a tömeghez” (many-to-many) típusú kommunikációra, akár egymással párhuzamosan is.

További jelentős különbség, hogy a reklám esetében az üzenet értékelésére több tényező áll a fogyasztó rendelkezésére (pl. közölt információk, az üzenet átadójának verbális és non-verbális kommunikációja stb.). Az e-WOM esetében azonban az értékelés nehézkes, és a fogyasztó az információ minősége mellett több tényezőt is figyelembe vehet az értékelésnél, úgy mint pl. a rendelkezésre álló információtömeg nagysága, a küldő észlelt tapasztalata vagy észlelt hitelessége (ld. pl. Cheung - Thadani, 2012).

A két eszköz hatását tekintve elmondható, hogy míg a reklámmal szemben a növekvő reklámzaj miatt általánosan elutasítóbbak a fogyasztók, az e-WOM-ot kevésbé tartják zavarónak. Ezzel párhuzamosan mindkét eszköz közel azonos hatást gyakorolhat a potenciális fogyasztókra: így hatással lehetnek többek között az ismertségre, az attitúdre vagy a márkaértékre is, ahogy az eladások közvetlen növekedésére is.

A WOM esetében korlátozó tényezóként jelentkezik, hogy a pozitív hatások jellemzóen a pozitív tartalom esetében érvényesülnek, hiszen egy adott termékről vagy szolgáltatásról szóló WOM lehet negatív tartalmú is. Az értékesítésre gyakorolt hatásra elmondható, hogy a hagyományos reklám tipikusan rövid távú eszköz (pl. árpromóció), míg az e-WOM esetében rövid, de hosszú távon is érvényesülhetnek az értékesítésre vonatkozóan pozitív és negatív hatások is.

A hatások mérésében a reklám esetében léteznek egyezményes mérések, pontos mutatószámok, míg az e-WOM esetében - egy közvetett marketingkommunikációs eszközrôl lévén szó - korlátozottabbak a mérési lehetőségek. Habár már léteznek olyan eszközök pl. a Social Mention vagy a Google Alerts, amelyek adott márkanév említését keresik a különböző platformokon. (A Social Mention a megadott kulcsszavakat keresi a különböző közösségimédia-felületeken, amely említésekről különböző statisztikákat is készít. A Google Alerts egy olyan alkalmazás, amely szinkron vagy aszinkron jelzi, hogy ha a megadott kulcsszavakkal kapcsolatban milyen újdonságok jelennek meg az on-line felületeken (tehát nemcsak a közösségi média felületeire fókuszál). Ha új megjelenést vagy változást tapasztal a rendszer a keresőszavakkal kapcsolatban, akkor egy e-mailt küld a felhasználónak. (2.táblázat)

\section{Az e-WOM típusai}

Az e-WOM típusainak fóbb csoportosítási ismérvei lehetnek az eredet, a tartalom és a megjelenési forma.

A hagyományos WOM esetében alkalmazható eredet szerinti csoportosítás az on-line formánál is alkalmazható. Ez alapján megkülönböztethetünk (1) organikus, (2) felerósített és (3) exogén WOM-ot (Armelini - Villanueva, 2010), vagy más néven (1) tapasztalati, (2) kapcsolódó és (3) célzott WOM-ot (Bughin et al., 2010).

1. Organikus (organic) WOM-ról beszélhetünk, amikor a fogyasztó önmagától - azaz külső ráhatás nélkül - egy vásárlási tapasztalatát vagy élményét írja le. Ez tekinthetố a WOM „legtermészetesebb” formájának, amikor a fogyasztó valós tapasztalatát és elégedettségét megosztja a többiekkel. Emiatt nevezik e kategóriát Bughin és szerzôtársai (2010) tapasztalati WOM-nak. A szerzők szerint az e-WOM 50-80 százalékát e megnyilvánulások teszik ki. Jó szemléltetô példa erre a kereskedelmi közösségi oldalakon megjelenő leírások, amelyek nemcsak a terméket, hanem magát az eladót is érintheti (pl. az Amazon felületén) vagy fogyasztóvédelmi blogok, ahol negatív vásárlási élményeiket osztják meg a fogyasztók (pl. homar.blog.hu).

2. Felerósített (támogatott) (amplified), vagy kapcsolódó (consequential) WOM-ról beszélhetünk ha van külső ráhatás (pl. a vállalat valamilyen módon bátorítja a fogyasztókat a tapasztalatok megosztására, vagy azt marketingkommunikációs tevékenység váltja ki), és ennek eredményeképpen beszélnek pozitívan a fogyasztók. Tipikus példája, amikor egy étterem különböző kedvezmények nyújtásával arra ösztönzi a vendégeket, hogy jelentkezzenek be az adott közösségimédia-felületre, ezáltal jelezve, hogy az adott étteremben vannak, vagy az az eset, amikor egy vállalat egy nyereményjátékot szervez a közösségimédia-felületén, és a fogyasztóknak nemcsak hozzá kell szólniuk, hanem meg kell osztaniuk az adott tartalmat.

3. Az exogén (exogenous), vagy célzott (intentional) a vállalatok által indított, ún. buzz marketing, vagy vírusmarketing törekvés. Ennek során a vállalat azonosítja a véleményvezérek szerepét, a digitális térben lévő főbb befolyásolókat, létrehoz e felhasználók részére támogató programokat, és bátorítja ôket a WOM „megalkotására”, valamint a vállalat maga is aktívan részt vesz a $\mathrm{C} 2 \mathrm{C}$ párbeszédekben. Bughin és szerzőtársai (2010) tanulmánya megjegyzi, hogy az ilyen célzott kampányok részesedése a teljes WOM-ból viszonylag mérsékelt, mivel kétséges az eredményük és nehezen mérhetóek. 
A célzott e-WOM - tulajdonképpen nem más, mint a szájreklámmarketing vagy röviden WOMM, ahol a vállalat különböző eszközökkel alakítja az e-WOM-ot - során kiemelt fontossággal rendelkező befolyásolókat hálózatelméleti fontosságuk alapján csomópontoknak (hub) nevezzük. Ök azok, akik kiemelkedő számú közvetlen kapcsolattal rendelkeznek egy adott hálózatban és nagy hatással és befolyással is rendelkeznek. Szerepüket jól példázza, hogy a közösségen belüli információáramlást e szereplők hatátozzák meg (Holczinger et al., 2013). Példa erre a típusra a Rézangyal TAG kampánya, amely során a vállalat olyan egyént keresett, aki kiterjedt kapcsolati hálóval rendelkezik off-line és on-line egyaránt. Majd a hub révén népszerúsítette a cég termékeit oly módon, hogy a „tag” eseményeket szervezett a márka támogatásával és ezekről, valamint a márkához kötődő egyéb élményeirôl a közösségimédia-felületeken számolt be.

Az e-WOM tartalma szerint beszélhetünk pozitív és negatív WOM-ról. Míg a pozitív WOM felfogható úgy, mint a fogyasztó hajlandósága a termék ajánlására más fogyasztók számára (Gruen et al., 2006), addig a negatív WOM egy termék/szolgáltatás gyengeségeit, problémáit hangsúlyozza ki, ezáltal próbálja eltántorítani a felhasználókat az elfogadástól és a használattól (Cheung - Thadani, 2012).

A pozitív és negatív e-WOM hatásmechanizmusát tekintve nincs egyetértés a szakirodalomban. Az egyik irányzat szerint összességében közel azonos a hatásuk (Ahluwalia, 2002), egy másik irányzat szerint a negatív WOM-nak szignifikánsabb hatása van, mint a pozitív WOM-nak (pl. Cheung et al., 2009). Ennek oka lehet, hogy a pozitív e-WOM sokszor sokkal általánosabb (Godes - Mayzlin, 2004), éppen ezért a negatív WOM által közvetített információknak nagyobb észlelt értéke van a fogyasztók számára (Sen - Lerman, 2007), míg a pozitív e-WOM esetében számolni kell bizonyos fogyasztói szkepticizmussal is.

A WOM vállalati alkalmazása szempontjából meghatározó empirikus eredmény, hogy a fogyasztók azt az információs környezetet érzékelik általánosan hitelesebbnek, ahol pozitív és negatív információk egyaránt jelen vannak (Cheung et al., 2009). A negatív oldal hiányában a fogyasztó ugyanis hajlamos lehet azt gyanítani, hogy a küldônek manipuláló szándéka lehet (Schindler - Bickart, 2005). Fontos ugyanakkor azt is figyelembe venni, hogy az e-WOM-nál megjelenó információk minősége különösen változó (Lee - Youn, 2009). E minőségi környezet is meghatározó abból a szempontból, hogy egy információforrást mennyire érzékel használhatónak és hatásosnak a fogyasztó. Így például az olyan információk, amelyek kizárólag a termék szubjektív minőségét írják le, kevésbé lesznek hatásosak egy potenciális fogyasztó számára, mint azok, amelyek széleskörúen taglalják a fogyasztói szemszögből észlelt terméktulajdonságokat és magát a termékhasználatot.

Az e-WOM csatornáinak száma az internetes alkalmazások fejlődésével párhuzamosan bővült. Fő megjelenési felületei közé tartoznak többek között a blogok, a mikroblogok, a fórumok, a hírcsoportok és az egyéb hírmegosztó szolgáltatások, a virtuális közösségek, a termékértékelő és bojkott oldalak, az on-line csevegószolgáltatások, az on-line márka/vásárlói/kereskedői oldalak és egyéb honlapok, illetve az e-mailek is (Bickart - Schindler, 2001; Litvin et al., 2008). A különböző csatornákon megjelenő e-WOM eltérő tulajdonságokkal rendelkezik (Cheung - Thadani, 2012), amelyből következik, hogy az egyes felületeken megjelenő e-WOM-ok hatása eltérő (Lee - Youn, 2009).

\section{Az e-WOM hatása}

Az e-WOM az egyik legbefolyásosabb információforrásnak tekinthetó, hiszen amint láthatóvá vált, vállalattól független információforrásnak tekintik a fogyasztók, így jobban bíznak ezen információkban, mint a vállalat által közzétett információkban. Hatásainak számossága szintén befolyásos szerepét támasztja alá.

$\mathrm{Az}$ e-WOM hatásainak esetében kétszintú folyamatról beszélhetünk, így megkülönböztethető vállalati és egyéni (fogyasztói) szint (Cheung - Thadani, 2012; Jalilvand et al., 2011). A vállalati hatások vizsgálata során a kutatási fókuszában az áll, hogy milyen hatást gyakorol az e-WOM a termék vagy a szolgáltatás piaci teljesítményére. A piaci (vállalati) szintú hatások vizsgálatakor az e-WOM tekinthetô úgy, mint egy általános fogyasztói vélemény - vagyis a fogyasztói vélemények összesített halmaza. Egyéni szinten vizsgálva pedig az e-WOM-ra úgy is tekinthetünk, mint a fogyasztói döntéshozatalban befolyással bíró informális folyamatra. Az off-line és e-WOM között a továbbiakban nem teszünk különbséget az egyéni és vállalati szintû hatásokban. (Habár a definícióban különbséget tettünk a WOM és e-WOM között, azonban alapvető tulajdonságaikat és múködési mechanizmusukat tekintve hasonlóak, így a legfóbb hatásokban sincs közöttük különbség.)

\section{A fogyasztói oldalról: egyéni hatások}

A szakirodalom többsége szerint az e-WOM-nak jelentôs befolyása van a vásárlási döntésre és a magatartásra (pl. Wangenheim - Bayón, 2004; Kemény - Simon, 2015). Néhány kutatási eredmény ezzel szemben arra enged következtetni, hogy a WOM-nak az anonimitás miatt nincs valós hatása (Guadagno - Cialdini, 2005). 
A szakirodalom a befolyásolási folyamat két fóbb típusát különbözteti meg: az információs, valamint a normatív befolyásolást (Park - Lee, 2009). Az információs befolyásolás alaptétele, hogy az egyén az információt, mint a valóság bizonyítékát fogadja el másoktól. Ezzel szemben a normatív befolyásolást úgy értelmezhetjük, mint az egyén más személyek vagy csoportok elvárásaival való konformitáskeresését.

Információs szempontból az e-WOM legnagyobb előnye a fogyasztók számára, hogy támogatja a döntéshozatalt (Park - Lee, 2009). Az e-WOM ugyanis jellegéből fakadóan fogyasztóorientált információkat szolgáltat (vagyis a termékattribútumok felsorolásán túlmutató, meglévő termékhasználatra alapozott fogyasztói észrevételeket és véleményeket nyújt), továbbá visszajelzést is ad egy termékről vagy szolgáltatásról (Gupta - Harris, 2010), közvetlen információhoz juttatva a potenciális fogyasztót még a vásárlás előtt.

Ezzel hozzájárul a döntéshozatallal kapcsolatos bizonytalanság csökkentéséhez. Ezen felül azzal, hogy több típusú információ egy helyen található meg, az e-WOM jelentős mértékben lerövidíti a döntési időt.

Habár a fogyasztó az e-WOM segítségével mennyiségében több információhoz juthat, az általános értékelés nehézkes lehet. Tekintve, hogy egy szemtól szembeni személyes kommunikáció az e-WOM esetében nem valósul meg, a hagyományos információértékelés főbb elemeiként használt információs tényezók megítélése (pl. küldő megbízhatósága) nem minden esetben lehetséges (Cheung - Thadani, 2012).

Az értékelés mellett az e-WOM esetében különösen kritikus pont az információs túltelítődés (information saturation) (Park - Lee, 2009). Ennek eredménye lehet, hogy a fogyasztó összezavarodik és/vagy jelentősen megnövekszik a keresési költsége és ideje. Ez a telítődés általában akkor következik be, amikor a rendelkezésre álló információ forrása bizonytalan, az információ kétértelmú, túl nagy az újdonságtartalma vagy túlságosan komplex. E tulajdonságok pedig nagymértékben jellemzőek az e-WOM során megjelenő információkra: sok esetben nem azonosítható például a forrás, egy témában egyszerre van jelen egymásnak ellentmondó pozitív és negatív információ is, illetve egy információ egyszerre több helyen és időben és különböző formátumban is megjelenhet.

Példaként szolgálhat a fogyasztókra gyakorolt hatásokra, amikor a fogyasztó egy szállás lefoglalása előtt végigolvassa a TripAdvisor felületén az adott szállásról szóló fogyasztói véleményeket. Ekkor már több, függetlennek tartott forrásból származó információval fog rendelkezni. Ez már egyfajta viszonyítási pontot biztosít számára a döntés meghozatalában egy olyan témakörben, ahol nem rendelkezik tapasztalattal és ismerettel. E vélemények támogathatják abban, hogy lefoglalja a szállást, vagy éppen ellenkezőleg, el is tántoríthatják. Ugyanakkor bekövetkezhet az is, hogy túl sok vélemény van, túlságosan semlegesek (ugyanannyi pozitív és negatív vélemény van) vagy nagyon semmitmondó információkat tartalmaznak. Ebben az esetben zavarodottságot okozhat a fogyasztóban a kapott információk tömege, így elfordulhat az adott szálláshelytôl.

$\mathrm{Az}$ e-WOM megjelenése a vásárlói környezetben is változásokat idézett eló, megerósítve a fogyasztók helyzetét a vállalattal szemben. Varadarajan és Yadav (2002) alapján az alábbi négy fó hatás erósíti a fogyasztó helyzetét az új, digitális kommunikációs környezetben: (1) a fogyasztók tartalom-elóállítókká válnak, ezáltal ôk maguk is hozzájárulnak az információs értékteremtéshez, (2) a fogyasztók számára több forrásból és nagy mennyiségben válik adottá a lehetôség a termékhez és a versenytársakhoz kapcsolódó információk beszerzésére, (3) csökken az információs aszimmetria, mivel a fogyasztók képessé válnak a versenytársak ajánlatainak áralapú és egyéb tulajdonságok szerinti összehasonlítására, (4) a fogyasztók közötti szabad és gyors információáramlás folyamatosan fejleszti az elérhető információk minőségét.

Összegezve az e-WOM fogyasztók szempontjából legfontosabb hatásait (2. ábra) elmondható, hogy információt nyújt, a döntéshozatalt támogatja, valamint megerősíti a fogyasztó helyzetét a vállalatokkal szemben.

\section{Az e-WOM hatása a fogyasztók szemszögéból}

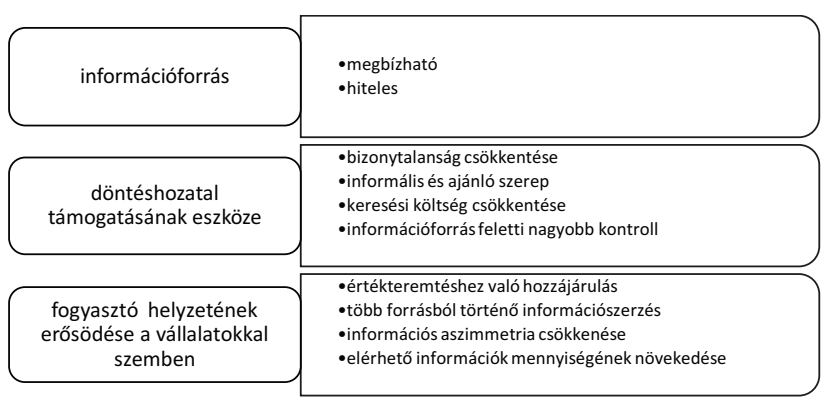

Forrás: saját szerkesztés

\section{A vállalati oldalról}

Az e-WOM pozitív szervezeti hatásai abban az esetben használhatók ki, ha rendelkezésre áll egy megfeleló szervezeti struktúra, amely a WOM-ot stratégiai információs inputként kezeli (Williams - Buttle, 2011), és képes azt aktívan (valós időben és megfeleló módon) menedzselni (Dellarocas, 2003). A stratégiai szintú kezelés során a teljes kommunikációs környezet figyelése elengedhetetlen, amibe beletartoznak a termék/szolgál- 
tatás, a kommunikációs folyamat, a véleményvezérek, a partnerek és a munkavállalók is. Egy vállalatnak az e-WOM kezelése során tudatában kell lennie annak is, hogy az lehetőséget és veszélyeket egyaránt rejt magában. A WOM egy globális jelenségnek tekinthetó, amely lehetôvé teszi a fogyasztók széles körú elérését és véleményük befolyásolását, relatíve alacsony költségek mellett. Kihívást és nehézséget jelenthet, hogy a felület jellemzője az anonimitás is, amely negatív, félrevezetó és eltérített fogyasztók által generált tartalmakat is eredményezhet.

A digitális kommunikációs hálózatok átalakíthatók „befolyásoló hálózatokká” (De Bruyn - Lilien, 2008), azaz ha a vállalat megfelelóen vesz részt a fogyasztók közötti kommunikációban, akkor az adott hálózatban (közösségben) ráhatással lehet az információáramlásra, ezáltal közvetlenül a résztvevókre. A fogyasztók között zajló párbeszédben való aktív - de nem erőszakos - részvétel eredményeként kialakulhat a vállalat és a fogyasztók között közvetlen kapcsolat, amely a fogyasztók elkötelezettségéhez vezethet.

Az elkötelezettség következménye lehet többek között, hogy

1. a fogyasztó bízni fog a vállalatban és a termékében vagy szolgáltatásában,

2. elkötelezettségének növekedésével a fogyasztó egyre nagyobb mértékú hozzájárulást hajlandó tenni az adott hálózatban zajló interakciókban,

3. a fogyasztók adott hálózaton belüli aktivitásának a növekedése maga után vonhatja a fogyasztói értékteremtés megjelenését: a vállalat értékes információkhoz juthat a fogyasztók révén pl. terméke vagy szolgáltatásával kapcsolatban, amelyeket felhasználhat fejlesztésre,

4. az elkötelezettség mélyülésével szoros kapcsolat alakulhat ki a fogyasztó és a vállalat között, amely eredményeként lojálissá válik a fogyasztó (Brodie et al., 2013), a lojális fogyasztók pedig akár márkaevangelistává is válhatnak (Scarpi, 2010).

Az elkötelezettség kialakulása és ennek következményei összességében versenyelóny-forrásokat biztosíthatnak a vállalat számára (Sedley, 2008).

Azonban a vállalatoknak a befolyásolás kialakításához és megtartásához szükséges meggyőzniük a felhasználókat arról, hogy egyfelól hajlandóak legyenek pozitív márkatapasztalataikat megosztani (pozitív organikus WOM), másfelől pedig saját kommunikációs csatornáikon továbbítsák a vállalat által létrehozott vagy támogatott információkat (célzott, illetve felerôsített WOM). E cél eléréséhez feltétel, hogy a szervezetek a piacon létrejövő új dinamikában részt vegyenek (Litvin et al., 2008). A vállalati részvételt támasztja alá az is, hogy a szúk, az üzenettel közvetlenül találkozó elsőd- leges célcsoport mellett e tagok önkéntes közvetítésével eljuthat az információ egy sokkal tágabb másodlagos célcsoport felé is (Csordás et al., 2012). Így elmondható, hogy a vállalatok végső célja a fogyasztói beszélgetések természetes részévé válás legyen (Kozinets et al., 2010).

Az e-WOM hatással lehet arra, hogy a terméket/ szolgáltatást elfogadják a fogyasztók, hiszen fontos ösztönzője az új technológiák fogyasztói adaptációjának (Godes - Mayzlin, 2004). Tekintve, hogy a fogyasztók az e-WOM-ot megbízható információforrásként kezelik, kétségtelen nagy szerepe van a vásárlási döntési folyamatban is, hiszen befolyása van a termék megítélésére és kiválasztására (Bone, 1995; Gruen et al., 2006).

Fontos kiemelni, hogy a(z on-line) WOM szerepe és hatása a termék életciklusa alatt változhat (Godes - Mayzlin, 2004): míg a bevezetés szakaszában kisebb mennyiségú, de jelentősebb hatású az e-WOM az ismertségnövelésben, addig az érettség szakaszában egyre nagyobb mennyiségú, és inkább megerősíto hatása lesz. A termék típusa is meghatározó (Park - Lee, 2009), hiszen kiemelt jelentőséget képvisel az e-WOM az egyén számára személyes szinten releváns termékek esetében (Csordás et al., 2012). Továbbá a tapasztalati és bizalmi termékek esetében lehetővé teszi a virtuális kipróbálhatóságot (Lepkowska-White, 2013).

Az e-WOM hatása nemcsak a termékre/szolgáltatásra, hanem a márkára is kiterjed. Jelentős hatásának tekinthető, hogy erős befolyása van a márka felidézésre, hiszen az e-WOM révén az adott márkával rendszeresen találkozik a fogyasztó. Továbbá az e-WOM pozitív attitúdváltozást képes elérni a márka irányába és hosszú távú megítélésében (Armelini - Villanueva, 2010), ezáltal tehát a márka építésére is hatása van (Dellarocas, 2003).

Empirikus kutatások bebizonyították (Chai - Kim, 2010; Dellarocas, 2003), hogy - egyebek közt a fentebb ismertetett hatások mentén - az e-WOM pozitív hatással van az átfogó vállalati teljesítményre a növekvő eladásokon, a felhasználók általi ismeretterjesztésen, valamint a fogyasztók aktivizálásán, a termékfejlesztésen, a minőségellenőrzésen és az ellátási lánc minőségén keresztül.

Példaként szolgálhat az e-WOM vállalati hatásaira az, amikor egy szálloda a honlapján feltünteti a róla írt TripAdvisor-os véleményeket, amellyel növelheti a bizalmat, hiszen a fogyasztói vélemény hitelességét átvetítheti saját márkájára. De további példaként tekinthetjük, amikor a TripAdvisor-on megjelenő negatív vélemények hatására a fogyasztók elfordulnak az adott szállástól, így a szállás potenciális bevételtől esik el.

Összegezve az e-WOM vállalatokra gyakorolt legfontosabb hatásait tekintve (3. ábra) elmondható, hogy lehetôséget ad befolyásolási hálózat kialakítására, a termék és márka építésére, valamint a vállalati teljesítmény is növelhető segítségével. 


\section{Az e-WOM hatásai vállalati szempontból}

\begin{tabular}{|c|c|}
\hline $\begin{array}{l}\text { befolyásolási } \\
\text { hálózat } \\
\text { kialakítása }\end{array}$ & $\begin{array}{l}\text { •központi befolyásolási csatorna lehetősége } \\
\text { •fogyasztói elkötelezettség (pl. bizalom, fogyasztói hozzájárulás növelése) } \\
\text { •lojalitás erősödése } \\
\text { •márkaevangelista fogyasztók }\end{array}$ \\
\hline $\begin{array}{l}\text { termék- és } \\
\text { márkaépítés }\end{array}$ & $\begin{array}{l}\text { •termékelfogadás, termékítélet } \\
\text { •termékészlelés, kiválasztás } \\
\text { •márkafelidézés, márkaattitüúd }\end{array}$ \\
\hline $\begin{array}{l}\text { vállalati } \\
\text { teljesítmény } \\
\text { növelése }\end{array}$ & \begin{tabular}{|l} 
•növekvő eladások \\
•termékfejlesztés \\
•minőségellenőrzés \\
•ellátási lánc minőségének fejlődése
\end{tabular} \\
\hline
\end{tabular}

Forrás: saját szerkesztés

Ahogy látható az e-WOM jelenségének jelentős szerepe van a fogyasztók döntéshozatalában, és a vállalat sikerességére is kihatással van. Éppen ezért fontos a vállalatok számára az e-WOM-nak mint eszköznek a felhasználása és integrálása a marketingkommunikációs tevékenységükbe.

Ezt elősegítendő beszélhetünk az e-WOM marketing fogalmáról. Az e-WOM marketing (e-WOMM) nem más, mint a fogyasztók közötti (C2C) kommunikáció szándékos befolyásolása/alakítása a vállalatok által különböző marketingtechnikákkal (Kozinets et al., 2010, p. 71.). A befolyásolás/ráhatás alapvetôen két módon történhet: indirekt vagy direkt módon.

Indirekt befolyásolás esetén a vállalat különböző marketingkommunikációs eszközökkel közvetett módon hathat a fogyasztók között zajló kommunikációra. Ennek egyik módja, ha a vállalat marketingkommunikációs tevékenysége a fogyasztók szerint szórakoztató, szokatlan vagy meghökkentő jellegú. Az ilyen jellegú tevékenységek (pl. ambient reklám) felkeltik a fogyasztók figyelmét és érdeklődését, akik megosztják az adott tartalmat, valamint hozzá fúződő gondolataikat, tapasztalataikat. Egy másik lehetséges indirekt mód az e-WOM generálásában, ha a vállalat biztosítja a felületet a fogyasztók számára, hogy megoszthassák élményeiket, tapasztalataikat, véleményüket kifejezetten a termékkel/ márkával kapcsolatban, és itt a fogyasztók márkaközösséget alkotva beszélgethessenek egymással.

A vállalat direkt módon is hathat az e-WOM kialakulására. Ezt a közvetlen módon való ráhatást Kozinets és munkatársai (2010) a hálózati együttmúködés modelljének (Network Coproduction Model) nevezik. Ennek során a vállalat közvetlenül kerül kapcsolatba egyes fogyasztókkal (one-to-one kommunikáció keretében) és veszi rá őket különböző (anyagi vagy egyéb jellegû) ösztönzőkkel, hogy osszák meg élményüket társaikkal különböző on-line felületen (many-to-many módon). Ezt a felületet akár maga a vállalat is biztosíthatja, de lehet akár a fogyasztók közötti kommunikáció céljából létrehozott bármilyen közösségimédia-felület is. A direkt ráhatás sikerességét meghatározza, hogy a megfeleló fogyasztót célozza-e meg a vállalat, hiszen az adott fogyasztó on-line közösségekben betöltött szerepe befolyásolja az üzenet terjedésének hatókörét. Minél inkább központi szerepet tölt be (tehát tekinthető hubnak) minél több közösségben az adott fogyasztó, annál több fogyasztóhoz jut el az üzenet (Holczinger et al., 2013).

\section{Összegzés}

Az e-WOM egyrészt a társas befolyásolás és kommunikáció egy formájának tekinthetô, amely alapvetően fogyasztók között zajlik. Folyamatában az e-WOM küldője (forrása) - aki múltbeli, aktuális vagy potenciális érintett (stakeholder) - többnyire verbális ingereket közvetít a közönség felé. Azonban képes ezt helyettesíteni vagy kiegészíteni teljes mértékben vizuális és/vagy audiovizuális ingerekkel. Az ingerek tartalma bármilyen pozitív, semleges vagy negatív állítás lehet a termékról, szolgáltatásról, márkáról, vállalatról vagy személyről. E tartalmak elérhetóek az on-line felületeken a fogyasztók és a szervezetek számára egyaránt, valamint lehetôségük van a válaszra is.

Az e-WOM lehet egy olyan kommunikációs eszköz is, amely a szúk, az üzenettel közvetlenül találkozó elsődleges célcsoport segítségével önkéntes közvetítéssel jut el egy sokkal tágabb másodlagos célcsoport felé. Mint kommunikációs eszköz, a vállalatok számára lehetôséget teremt az információterjesztésben történő részvételre és a befolyásolásra, a fogyasztók számára pedig az aktivitásra és interaktív kommunikációra, ezáltal hatalmi pozíciójuk erősítésére.

$\mathrm{Az}$ e-WOM marketingkommunikációs eszközként való kezelésének szükségességét, vagyis az e-WOM marketingalkalmazását támasztja alá a fogyasztókra és a vállalatra tett hatásainak számossága és kiterjedtsége.

Látható tehát, hogy az e-WOM folyamatának minél mélyebb megismerése lehetôség nyújt a vállalatok számára arra, hogy jobban megismerjék fogyasztóikat, velük kapcsolatot alakíthassanak ki, és az új, megváltozott környezetben ráhatással legyenek a fogyasztók között zajló kommunikációra.

\section{Felhasznált források}

Archer-Brown, C. - Piercy, N. - Joinson, A. (2013): Examining the information value of virtual communities: Factual versus opinion-based message content. Journal of Marketing Management, Vol. 29, No. 3-4: p. 421-438. 
Armelini, G. - Villanueva, J. (2010): Marketing Expendutures and Word-of Mouth Communication: Complements or Substitutes? (Vol. 5): Foundations and Trends in Marketing. Now Publishers Inc.

Bergamo, M. - Bagozzi, R. P. (2000): Self-categorization, affective commitment and group self-esteem as distinct aspects of social identity in the organization. British Journal of Social Psychology, Vol. 39, No. 4: p. 555-577.

Bickart, B. - Schindler, R. M. (2001): Internet forums as influential sources of consumer information. Journal of Interactive Marketing, Vol. 15, No. 3: p. 31-40.

Bonchek, M. (2015): Why Customer Gratitude Trumps Loyalty. Harvard Business Review (on-line), Oct 19, 2015. URL: https://hbr.org/2015/10/why-customer-gratitude-trumps-loyalty. Letöltve: 2015. okt. 19.

Bone, P. F. (1995): Word-of-Mouth Effects on ShortTerm and Long-Term Product Judgment. Journal of Business Research, Vol. 32, No. 3: p. 213-223.

Botha, E. - Farshid, M. - Pitt, L. (2011): How sociable?: An exploratory study of university brand visibility in social media. South African Journal of Business Management, Vol. 42, No. 2: p. 43-51.

Brodie, R. J. - Ilic, A - Juric, B. - Hollebeek, L. (2013): Consumer engagement in a virtual brand community: An exploratory analysis. Journal of Business Research, Vol. 66, No. 1: p. 105-114.

Bughin, J. - Doogan, J. - Vetvik, O. J. (2010): A new way to measure word-of-mouth marketing. McKinsey Quarterly, Vol. 2: p. 113-116.

Chai, S. - Kim, M. (2010): What makes bloggers share knowledge? An investigation on the role of trust. International Journal of Information Management, Vol. 30, No. 5: p. 408-415.

Cheung, C.M., - Thadani, D. R. (2012): The impact of electronic word-of-mouth communication: A literature analysis and integrative model. Decision Support Systems, Vol. 54, No. 1: p. 461-470.

Cheung, M. Y. - Luo, C. - Sia, C. L. - Chen, H. (2009): Credibility of Electronic Word-of-Mouth: Informational and Normative Determinants of On-line Consumer Recommendations. International Journal of Electronic Commerce, Vol. 13 No. 4: p. 9-38.

Cova, B. - Cova, V. (2002):. Tribal marketing: The tribalisation of society and its impact on the conduct of marketing. European Journal of Marketing, Vol. 36. No. 5/6: p. 595-620.

Csordás, T. (2016): A fogyasztói részvétel mint marketingkommunikációs eszköz a digitális médiában (User participation as a marketing communications tool in the age of digital media). Doktori (PhD) értekezés. Budapest: Budapesti Corvinus Egyetem, Gazdálkodástani Doktori Iskola. URL: http://phd. lib.uni-corvinus.hu/891/
Csordás,T. - Nyiró, N. - Horváth, D. (2012): A fogyasztói részvétel fogalmi keretrendszere a marketingtudományban. A Magyar Marketing Szövetség Marketing Oktatók Klubja 18. Országos Konferenciája, Miskolci Egyetem, Miskolc, 2012. augusztus 30-31.

De Bruyn, A. - Lilien, G. L. (2008): A multi-stage model of word-of-mouth influence through viral marketing. International Journal of Research in Marketing, Vol. 25, No. 3: p. 151-163.

Dellarocas, C. (2003): The Digitization of Word of Mouth: Promise and Challenges of On-line Feedback Mechanisms. Management Science, Vol. 49, No. 10: p. 1407-1424.

eMarketer (2014): Do Consumers Actually Trust Reviews?. URL: http://www.emarketer.com/Article/ Do-Consumers-Actually-Trust-Reviews/1011744. Letöltve: 2014. 12. 01.

eMarketer (2015): Web Users Put More Stock in Consumer Reviews. URL: http://www.emarketer.com/ Article/Web-Users-Put-More-Stock-Consumer-Reviews/1012929. Letöltve: 2015. 08. 10.

Eszes, I. (2010): Szóbeszéd marketing. URL: http:// www.eszes.net/eTanulmanyok/WOM_szobeszedmark_Eszes.pdf. Letöltve: 2013.08. 10.

Fehér, K. (2011): Interaktív performance. Az új média platformjai, az ágens és a közösségek. in: Bányai, E. - Novák, P. (Eds.): On-line üzlet és marketing. Budapest: Akadémiai Kiadó: p. 52-71.

Godes, D. - Mayzlin, D. (2004): Using On-line Conversations to Study Word-of-Mouth Communication. Marketing Science, Vol. 28, No. 4: p. 545-560.

Green, J. - Jenkins, H. (2011): Spreadable Media: How Audiences Create Value and Meaning in a Networked Economy. in: Nightingale, V. (Ed.): The Handbook of Media Audiences. Malden, MA: Wiley-Blackwell: p. 109-146.

Gruen, T. W. - Osmonbekov, T. - Czaplewski, A. J. (2006): eWOM: The impact of customer-to-customer on-line know-how exchange on customer value and loyalty. Journal of Business Research, Vol. 59, No. 4: p. 449-459.

Guadagno, R. E. - Cialdini, R. B. (2005): On-line persuasion and compliance: Social influence on the Internet and beyond.

Henning- Thurau, T. - Gwinner, K. P. - Walsh, G. Gremler, D. D. (2004): Electronic word-of-mouth via consumer-opinion platforms: What motivates consumers to articulate themselves on the Internet? Journal of Interactive Marketing, Vol. 18, No. 1: p. 38-52.

Hirschmann, A. O. (1970): Exit, voice and loyalty. Responses to Decline in Firms, Organizations, and States. Cambridge.

Holczinger, D. - Csordás, T. - Markos-Kujbus, É. (2013). A befolyásolás típusai a hagyományos és az 
on-line szóbeszédmarketing esetében. Paper presented at A Magyar Marketing Szövetség Marketing Oktatók Klubja 19. Országos Konferenciája, Budapest, Hungary.

Jalilvand, M. R. - Esfahani, S. S. - Sameie, N. (2011): Electronic word-of-mouth: Challenges and opportunities. Procedia Computer Science, Vol. 3: p. 42-46.

Katz, E. - Lazarsfeld, P. F. (1955): Personal Influence, the Part Played by People in the Flow of Mass Communications. New York: Free Press

Kemény, I. - Simon, J. (2015): Termékek és szolgáltatások vásárlása on-line-vajon mások az elvárások?. Vezetéstudomány/Budapest Management Review, Vol. 46. No. 7: p. 28-40.

Kotler, P. - Keller, K. L. (2006): Marketing management (12. ed.). Upper Saddle River, NJ.: Prentice Hall

Kozinets, $R$. V. (1999): E-tribalized marketing?: the strategic implications of virtual communities of consumption. European Management Journal, Vol. 17, No. 3: p. 252-264.

Kozinets, R. V. - De Valck, K. - Wojnicki, A.C. - Wilner, S. J. S. (2010): Networked Narratives: Understanding Word-of-Mouth Marketing in On-line Communities. Journal of Marketing, Vol. 74, No. 2: p. 71-89.

Lee, M. - Youn, S. (2009): Electronic word of mouth (eWOM): How eWOM platforms influence consumer product judgement International Journal of Advertising, Vol. 28, No. 3: p. 473-499.

Lepkowska-White, E. (2013): Are they listening? Designing on-line recommendations for today's consumers. Journal of Research in Interactive Marketing, Vol. 7, No. 3: p. 182 - 200.

Lievrouw, L. A. (2009): New media, mediation, and communication study 1 . Information, Communication - Society, Vol. 12, No. 3: p. 303-325.

Litvin, S. W. - Goldsmith, R. E. - Pan, B. (2008): Electronic word-of-mouth in hospitality and tourism management. Tourism Management, Vol. 29, No. 3: p. 458-468.

Markos-Kujbus, É. (2013): Az on-line szájreklám, mint a marketingkommunikáció eszköze. A Magyar Marketing Szövetség Marketing Oktatók Klubja 19. Országos Konferenciája, Budapesti Gazdasági Fơiskola, Budapest, 2013. augusztus 30-31.

Napoli, P. M. (2008): Toward a model of audience evolution: new technologies and the transformation of media audiences. McGannon Center Working Paper Series. Paper 15. URL: http://fordham.bepress.com/ mcgannon_working_papers/15, Letöltve: 2014. 10. 01 .
Okazaki, S. (2009): The Review of Marketing Communications. International Journal of Advertising, Vol. 28. No. 3: p. 61-67.

Park, C. - Lee, T. M. (2009): Information direction, website reputation and eWOM effect: A moderating role of product type. Journal of Business Research, Vol. 62, No. 1: p. 61-67.

Rab, Á. (2011): Bevezetés az információs társadalomba. in: Bányai, E. - Novák, P. (Eds.): On-line üzlet és marketing (p. 16-34). Budapest: Akadémiai Kiadó

Sándor, I., - Horváth, D. (2008): A marketingkommunikáció alapjai. Jegyzet. Budapest: Budapesti Corvinus Egyetem

Scarpi, D. (2010): Does size matter? An examination of small and large web-based brand communities. Journal of Interactive Marketing, Vol. 24, No. 1: p. 14-21.

Schindler, M. R. - Bickart, B. (2012): Perceived helpfulness of on-line consumer reviews. Journal of Consumer Behaviour, Vol. 11, No. 3: p. 234-243.

Sen, S. - Lerman, D. (2007): Why are you telling me this? An examination into negative consumer reviews on the Web. Journal of Interactive Marketing, Vol. 21. No. 4: p. 76-94.

Statista (2015): Do you trust on-line customer reviews as much as personal recommendations? . URL: http://www.statista.com/statistics/315755/on-linecustmer-review-trust/, Letöltve: 2015. 08. 10.

Varadarajan, R. P. - Yadav, M. S. (2002): Marketing strategy and the internet: An organizing framework. Journal of the Academy of Marketing Science, Vol. 30, No. 4: p. 296-312.

Vilpponen, A. - Winter, S. - Sundqvist, S. (2006): Electronic Word-of-Mouth in On-line Environments: Exploring Referral Network Structure and Adoption Behavior. Journal of Interactive Advertising, Vol. 6, No. 2: p. 63-77.

Wangenheim, F. - Bayón, T. (2004): The effect of word of mouth on services switching: Measurement and moderating variables. European Journal of Marketing, Vol. 38, No. 9/10: p. 1173-1185.

Williams, M. - Buttle, F. (2011): The Eight Pillars of WOM management: Lessons from a multiple case study. Australasian Marketing Journal (AMJ), Vol. 19, No. 2: p. 85-92.

Yap, K. B. - Soetarto, B., - Sweeney, J. C. (2013): The relationship between electronic word-of-mouth motivations and message characteristics: The sender's perspective. Australasian Marketing Journal (AMJ), Vol. 21, No. 1: p. 66-74. 